\title{
Soft System Methodology (SSM) Analysis to Increase the Number of Prospective Students
}

\author{
Analisis Soft System Methodology (SSM) untuk Meningkatkan Jumlah Calon \\ Mahasiswa
}

Received:

17 August 2019

Revised:

18 November 2019

Accepted:

16 December 2019

\author{
${ }^{\text {1* }}$ Neilin Nikhlis, ${ }^{2}$ Ade Iriani, ${ }^{3}$ Kristoko Dwi Hartomo \\ ${ }^{1,2,3}$ Magister Sistem Informasi, Universitas Kristen Satya Wacana \\ ${ }_{1,2,3}$ Salatiga, Indonesia \\ E-mail:" neilin.nikh@gmail.com,2ade.iriani@uksw.edu, \\ ${ }^{3}$ kristoko@gmail.com \\ *Corresponding Author
}

\begin{abstract}
The competition between campus, whether it's a public college and private college in Central Java, is very tight with the increasing number of interested students for prospective students from various regions. The close competition requires many campuses to compete to provide the best facilities and services. The research objective is expected to support the "XY" university promotion strategy to help the university in the knowledge capture process. Data collection was carried out using the group discussion forum (FGD) method with a structured interview process for university leaders, university officials, marketing departments, and students. The technique used in this study is a soft system methodology (SSM). The results of this study model knowledge capture (KC) on the "XY" university promotion strategy and produce knowledge documentation that provides benefits in making policy strategies and has an impact on increasing the number of prospective new college students by optimizing digital marketing.
\end{abstract}

Keywords - Promotion Strategy, Soft System Methodology, Knowledge Capture

Abstrak - Era persaingan kampus baik perguruan tinggi negeri (PTN) dan perguruan tinggi swasta (PTS) di Jawa Tengah sangatlah ketat dengan semakin banyaknya peminat calon mahasiswa baru dari berbagai daerah. Persaingan yang ketat mengharuskan banyak kampus berlomba-lomba dalam memberikan fasilitas dan pelayanan terbaik. Tujuan penelitian diharapkan dapat menunjang strategi promosi universitas " $X Y$ " dalam proses knowledge capture. Pengumpulan data dilakukan menggunakan metode forum group discussion (FGD) dengan proses wawancara terstruktur kepada pimpinan universitas, pejabat universitas, bagian pemasaran serta mahasiswa. Jenis penelitian ini adalah kualitatif deskriptif serta menggunakan pendekatan soft system methodology. Hasil penelitian ini dapat memodelkan knowledge capture (KC) pada strategi promosi universitas "XY" serta menghasilkan knowledge documentation yang memberikan manfaat dalam pengambilan strategi kebijakan serta berdampak pada peningkatan jumlah calon mahasiswa baru dengan mengoptimalkan pemasaran digital.

Kata Kunci-Strategi Promosi, Soft System Methodology, Knowledge Capture

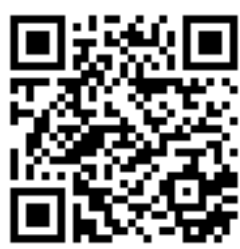

INTENSIF: Jurnal Ilmiah Penelitian dan Penerapan Teknologi Sistem Informasi 
INTENSIF, Vol.4 No.1 February 2020

ISSN: 2580-409X (Print) / 2549-6824 (Online)

DOI: https://doi.org/10.29407/intensif.v4i1.13552

\section{INTRODUCTION}

A tertiary institution (PT) is one of the higher education subsystems whose main task is to provide education and knowledge to students by the tri dharma of tertiary institutions. Currently, in Indonesia, there are two types of tertiary institutions that are held in the form of state universities (PTN), which are managed by the state and private universities (PTS) that are governed by the private sector. It causes competition between PTN and PTS in attracting prospective students to study by offering a variety of study programs with their respective advantages.

Prospective students have many options to continue their studies at universities that match their interests and abilities. Before making a decision a lot, it needs to be considered because college is one of the long-term investments. Many factors make prospective students make decisions in choosing a campus or college, including all stakeholders (stakeholders). Many stakeholders are involved in the college selection process, including being influenced by users or service users, initiators, or who create ideas, deciders or (decision-makers), influencers or influential people, and trust or level of trust [1].

In this case, universities are required to be able to make strategic policies to support the achievement of promotional goals to obtain satisfactory results, where the goal achieved is to increase the number of prospective students when the new school year begins. Various forms and promotion efforts have been carried out by universities, institutes, or universities involving many people. This activity raises a new way of thinking about promotion.

It is new in the system-wide way of thinking in the promotion process by looking at the problem thoroughly, not separately and starting from the data that has been collected by the promotion and followed up with data processing which can later become an information and its purpose so that it can become a knowledge by all stakeholders as an effective means of promotion. All experience (wisdom) so that it can be utilized as an effective promotional strategy should be captured and recorded using the Knowledge Capture (KC) concept and Soft System Methodology (SSM) approach, which is part of KM or Knowledge Management [2]. To provide adequate scope, KM needs to be determined in advance in the promotional strategy component [3]. Knowledge Management is a discipline and a function where knowledge is created, obtained, shared, and can be applied through an environment and be decisive in increasing breakthroughs (innovation) for organization performance [4] [5].

Knowledge management can foster competition mechanisms in every process of strategic organization decision making and can improve knowledge collectively and achieve the sustainability of a company or organization [6] [7]. A flexible system approach is used to 
INTENSIF, Vol.4 No. 1 February 2020

ISSN: 2580-409X (Print) / 2549-6824 (Online)

DOI: https://doi.org/10.29407/intensif.v4i1.13552

analyze problems that are not structured clearly and have not been well defined [8]. Soft System Methodology (SSM) is a systemic research process that uses system models, where SSM can produce a framework in dealing with even complex problems [9]. The development of the system model is carried out by exploring unstructured issues, discussing them intensively with all stakeholders, and solving problems together.

$\mathrm{XY}$ Higher Education is one of the tertiary institutions in the Central Java region, which has several campuses that have developed in more than two major cities in Central Java. XY Higher Education has eight excellent study programs consisting of various levels starting from D3, D4, and S1, which are spread across several campuses, which are located far in geographical areas. The problem with the promotion section is that it is constrained by a portal service on the campus website and is not yet separate according to the characteristics of branches outside the city.

Higher Education $\mathrm{XY}$ modeling $\mathrm{KC}$ (Knowledge Capture) as a reference in developing higher education promotion strategies so that the Soft Systems Methodology (SSM) approach which can be seen in Figure 1 can facilitate the process of capturing and documenting knowledge from promotional activities and then designing human activity systems. to achieve this promotional goal. It is hoped that the results of this strategy will have an impact on improving the quality of promotional activities in the community as a promotional target. This is related to information systems that are efficient in the process of increasing the speed of knowledge sharing.

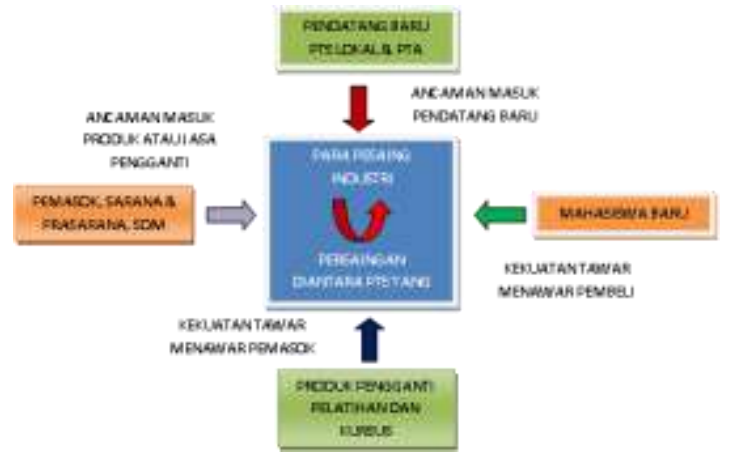

Figure 1. COMPETITIVE STRATEGy In THE SERVICE INDUSTRY OF UNIVERSITY

In a study entitled "Application of Knowledge Capture for Faculty Promotion Using Soft System Methodology (SSM) (Case Study: Faculty of Engineering, Sory Victory University)," in modeling KC (knowledge capture) can provide the results of several documents that can be utilized by the campus in help provide ideas on promotional strategies to target targets and prepare a proportional promotion budget [2]. 
INTENSIF, Vol.4 No.1 February 2020

ISSN: 2580-409X (Print) / 2549-6824 (Online)

DOI: https://doi.org/10.29407/intensif.v4i1.13552

There is another research with the title "Application of Knowledge Extraction in Payment for Lectures Using Soft System Methodology (Case Study: Higher Education X)," which tries to analyze problems related to the process of paying tuition fees at tertiary institutions by making a model in the process of knowledge extraction using the Soft System method Methodology [10]. Based on these events, so that Knowledge Capture (KC) with the Soft System Methodology (SSM) approach in the concept of Knowledge Management (KM) becomes meaningful learning for an institution or organization. A good organization can advance a piece of knowledge through the process of experience sharing in every individual in the organizational environment. Knowledge Management (KM) will move forward if there is strengthening management and supported by infrastructure in knowledge sharing so that it can cling to a strong character and not be quickly lost [11]. In this study, there is one thing that becomes an important point or differentiator, where the object of research or campus understudy has quite a lot of branches and is spread in more than two cities, thus requiring a concept of knowledge management (KM).

\section{RESEARCH METHOD}

The research methodology uses systematic based on seven steps using the soft system methodology (SSM) approach, which will be explained in the description of the problem situation so that knowledge capture (KC) modeling can be carried out. Data collection techniques by conducting observations, structured interviews, and FGDs involving respondents consisting of four (4) groups, namely leaders of universities, campus officials, the promotion department, and students.

\section{A. Problem Resolution Framework}

In the stages of the problem-solving framework depicted in Figure 2, where problem-solving is divided into two components in the form of case study analysis and knowledge capture modeling. The bolded boxes in the problem-solving framework are a process that is followed up based on the steps of the soft system methodology (SSM) approach. The problem situation (problem situation) in XY colleges (PT) is elaborated by case study analysis, describing the problem situation in the form of precious pictures, the next step is to identify the knowledge goals and knowledge needs of XY tertiary institutions, then carry out a transformation (process formulation) so PT goals can be achieved through holon, root definition and a framework for PT. XY The last stage is by doing knowledge capture modeling at XY colleges. The framework of problem-solving as an objective in this study is attached as follows [12]: 
INTENSIF, Vol.4 No.1 February 2020

ISSN: 2580-409X (Print) / 2549-6824 (Online)

DOI: https://doi.org/10.29407/intensif.v4i1.13552

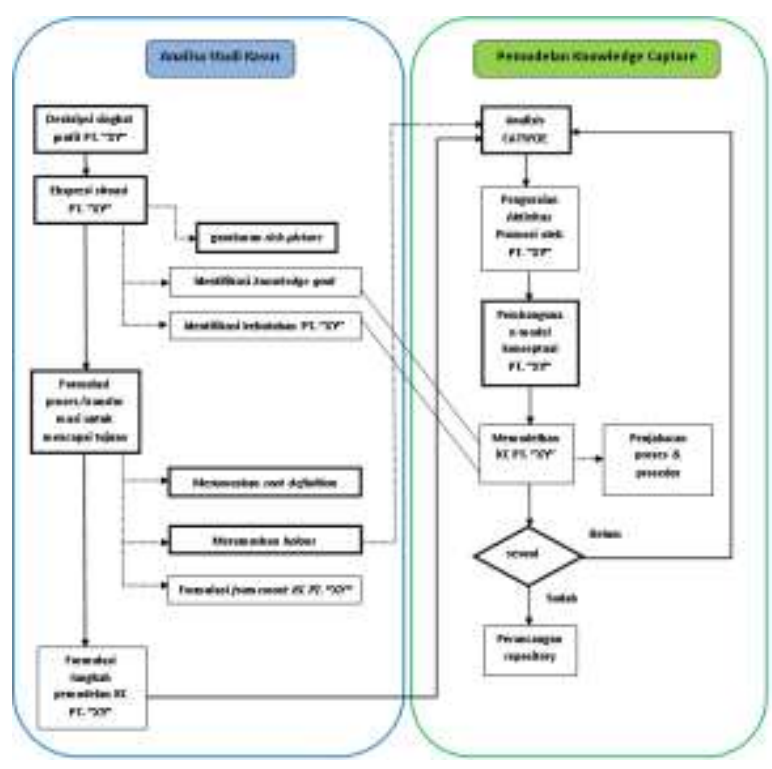

Figure 2. PROBLEM-SOLVING FRAMEWORK

\section{B. Description of Problem Situation}

Data collection techniques carried out in this method using interviews, observation, and focus group discussions (FGD). Structured and systematic interviews consisted of four groups of respondents [13]. In this study the knowledge capture technique (KC) was carried out using a soft systems methodology (SSM) approach in the "XY" college promotion strategy in increasing the number of students, at which stages are shown in Figure 3 [14]:

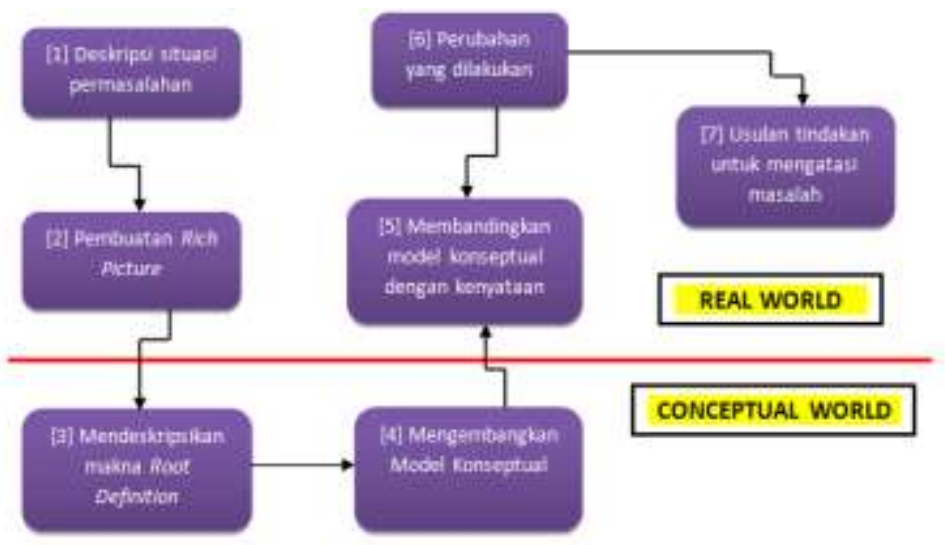

Figure 3. FRAMEWORK SOFT SYSTEM METHODOLOGY

\section{Problem Situation Description}

The first stage is carried out by conducting a process of identification and a brief description of the situation of the problems that occur in the organization so that solutions give to improve the case based on holistic analysis and systems thinking by conducting structured interviews using group discussion forum techniques (FGD) in exploring existing problems. 
INTENSIF, Vol.4 No.1 February 2020

ISSN: 2580-409X (Print) / 2549-6824 (Online)

DOI: https://doi.org/10.29407/intensif.v4i1.13552

\section{Express the Problem Situation (rich picture)}

The second stage that needs to be done is collecting data and information based on FGD techniques and described in the detailed description.

\section{Perform root definitions Related to the problem situation}

The third stage is making root definition (an expression of activities to be modeled that aims as a process of transformation until it changes form into an output process) based on problem situations by analyzing root definition by formulating holon or the method of describing a perspective that explains the activity system humans who are connected to achieve organizational goals by their original state by using CATWOE (Customers, Actors, Transformation, Owners, Environmental constraints) as problem-solving [15] [16].

\section{Create a Conceptual Model}

The fourth stage is conceptual modeling (an activity system model that consists of several elements of activity and is obtained by extracting all verbs that have an impact on the root definition) based on the third stage [8].

\section{Compare conceptual world with the real world}

The fifth stage compares the theoretical model with the description in the second stage (realworld situation).

\section{Carry out the Desired Change Process}

The sixth stage is the steps to change that are carried out on real-world conditions or situations that are considered unfavorable, such as structure, SOP, or individual attitudes.

\section{Perform An Evaluation or Correction of the problem situation}

The seventh stage is the stage that is carried out to improve the current SOP.

\section{RESULT AND DISCUSSION}

Following is the explanation and explanation of the results of the analysis in the stages of the soft system methodology (SSM) approach:

\section{A. Problem Situation}

Based on the results of a structured interview using the group discussion forum (FGD) technique to stakeholders in the "XY" tertiary institution, several problems in the promotion strategy that occurred were the geographical constraints and demographic characteristics of the different prospective students in each branch of the campus. The considerable distance and conditions of various aspects of the community create difficulties in the promotion division in creating effective and efficient promotional strategies. 
INTENSIF, Vol.4 No.1 February 2020

ISSN: 2580-409X (Print) / 2549-6824 (Online)

DOI: https://doi.org/10.29407/intensif.v4i1.13552

\section{B. Rich Picture}

The second process is to express the situation of the "XY" college promotion strategy in the form of a rich picture in Figure 4 explained :

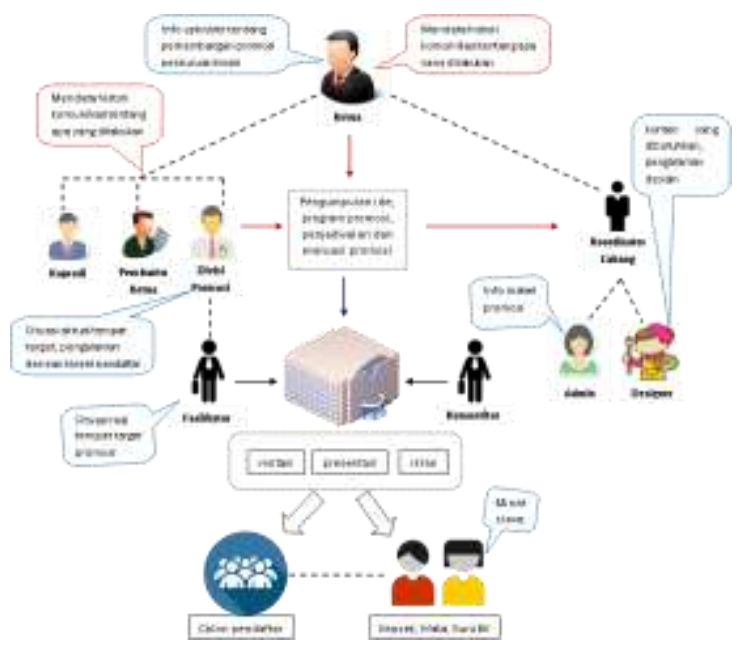

Figure 4. Rich PICTURE OF HIGHER EDUCATION "XY"

Based on the vibrant image that explains the situation in "XY" colleges, where the actors who come from within the college (chairman, assistant chair, head of study program, promotion division, coordinator, administration, designer and facilitator) and actors from outside (candidates registrants, competitors, principals, vice-principals and counseling teachers). In rich picture can be described the types of promotional activities and the attachment of each actor that can be defined on the fulfillment of the needs of each actor (individual).

\section{Analysis CATWOE}

To formulate root definitions (modeling activity systems) and holons (perspectives that describe human activity systems in achieving organizational goals) are mapped in the CATWOE analysis to solve the problem in the table 1.

Table 1. CATWOE ANALYSIS

\begin{tabular}{lll}
\hline \hline C & Customer & Head of College, Assistant Head, Head of Study Program, Students \\
\hline $\mathbf{A}$ & Actor & Assistant Chairperson, Head of Study Program, Promotion Division, \\
& & Coordinator, Administration, Designer, and Facilitator \\
\hline $\mathbf{T}$ & Transformation & To realize the right promotional strategy and have an impact on the increasing \\
& & number of prospective college students "XY," and can make budget plans and \\
& & promotional materials. \\
\hline $\mathbf{W}$ & World view & All "XY" college stakeholders work together to create effective and efficient \\
& & promotion strategies. \\
\hline $\mathbf{O}$ & Owner & Head of College \\
\hline $\mathbf{E}$ & Environment & An integrated promotion strategy is needed to increase the number of \\
& & prospective students.
\end{tabular}


INTENSIF, Vol.4 No.1 February 2020

ISSN: 2580-409X (Print) / 2549-6824 (Online)

DOI: https://doi.org/10.29407/intensif.v4i1.13552

\section{Conceptual Modelling}

Based on the college promotion strategy "XY," which has been described in the rich picture above, we obtain several elements in the formation of conceptual modeling depicted in Figure 5 which is a modeling image :

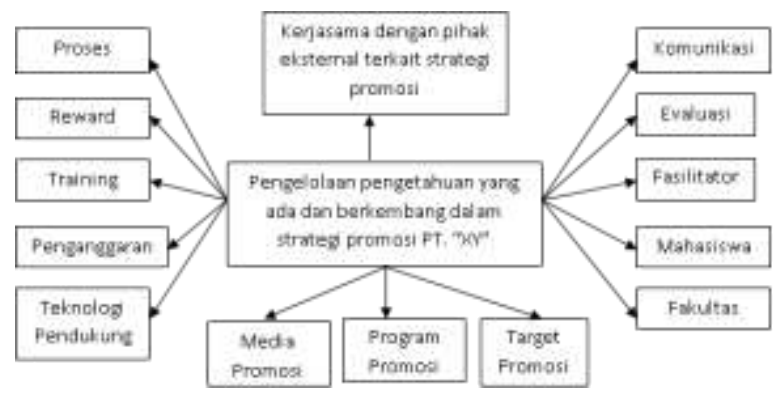

Figure 5. KNOWLEDGE CAPTURE DESIGN CONCEPTUAL MODEL

\section{HIGHER EDUCATION PROMOTION STRATEGY}

Figure 5, which is a conceptual modeling image, is designed based on promotional strategies followed by identifying root definitions based on the problem situation. In achieving this, the support factor will be explained in making a perspective shaped in perspective with some routine "XY" college promotion activities.

\section{E. Knowledge Capture pada Strategi Promosi}

In designing conceptual modeling that has been built, the promotion strategy has been outlined by the "XY" college, wherein Figure 6 shows a knowledge management model (KM) promotion strategy that can be carried out by the "XY" college.

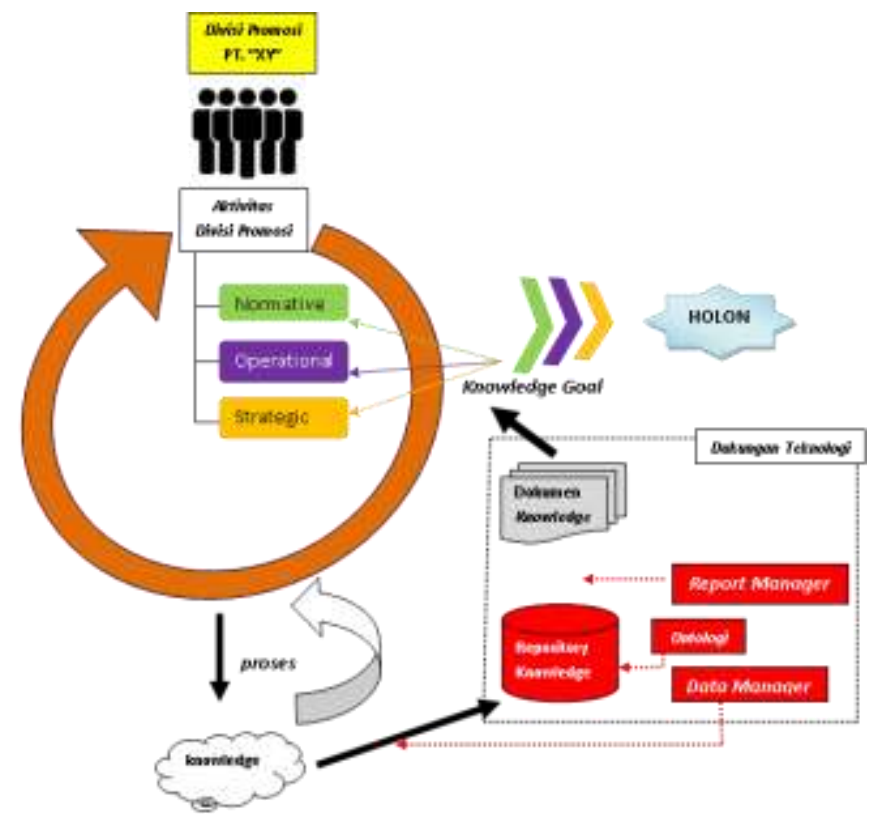

Figure 6. KNOWLEDge MANAGEMENT MOdEL Of Higher EdUCATION "XY" 
Explanation of some elements of the activation process of the "XY" higher education promotion strategy can be seen in Figure 6, where items in promotion activities are divided into three levels, namely normative, operational, and strategic. Normative standard is used to measure the application of employee behavior in the promotion section in carrying out activities according to established procedures, then the operational level where employees in the promotion section can carry out methods according to the document collection process from superiors and carry out promotional activities effectively, and finally the strategic level is the process produce strategic decisions (long term) based on structured knowledge data stored to achieve knowledge goals [2]. Figure 6 shows that between knowledge resources and knowledge, results can be paired, where the level is based on the purpose of experience in the implementation of knowledge management $(\mathrm{KM})$ contained in the knowledge goal. It is essential where knowledge management refers to knowledge sharing in the right place and accordance [17].

"XY" college promotion activities can produce the desired change or are often called holon. In promotional events, there is also a non-structured knowledge, so it is necessary to have technology support such as management reports and data managers as a tool in supporting a process of recording experience into a knowledge repository. In a deposit, an ontology must be made as part of the mechanism to make the process of data structure that has been obtained.

Reports and data managers in the form of software that can experience changes in the way of input devices and reports generated are tailored to developing knowledge. The SSM implementation model can illustrate the problems of promotional strategies in the form of branch offices. Knowledge repository is fundamental in supporting the "XY" college knowledge stored in a structured way so that ontology can have the function as available grammar related to the understanding that develops in the promotion system. 
INTENSIF, Vol.4 No.1 February 2020

ISSN: 2580-409X (Print) / 2549-6824 (Online)

DOI: https://doi.org/10.29407/intensif.v4i1.13552

\section{F. Comparison of the conceptual model and real world}

Table 2 is the result of a comparison of conceptual models and real world.

Table 2. COMPARISON OF CONCEPTUAL MODEL \& REAL WORLD

\begin{tabular}{|c|c|c|}
\hline Activity & Reality & Recommendation \\
\hline $\begin{array}{l}\text { Implementation of promotion } \\
\text { strategies }\end{array}$ & $\begin{array}{l}\text {-The application of the } \\
\text { promotion in detail is the full } \\
\text { responsibility of the branch } \\
\text { coordinator. } \\
\text { - Promotion division } \\
\text { prepares uniform } \\
\text { promotional materials for all } \\
\text { branches. }\end{array}$ & $\begin{array}{l}\text {-Involve active students as } \\
\text { agents in the recommendation } \\
\text { of MARU candidates by } \\
\text { giving rewards. } \\
\text {-The promotion division } \\
\text { creates an integrated } \\
\text { promotion strategy by } \\
\text { adjusting demographic } \\
\text { characteristics and } \\
\text { geographical location. }\end{array}$ \\
\hline $\begin{array}{l}\text { Collaboration with high school } \\
\text { / vocational schools }\end{array}$ & $\begin{array}{l}\text { "XY" colleges are promoting } \\
\text { pamphlets and brochures to } \\
\text { high schools / vocational } \\
\text { high schools. }\end{array}$ & $\begin{array}{l}\text {-Conduct educational events } \\
\text { to introduce "XY" colleges } \\
\text {-Cooperate training on hard } \\
\text { skills and soft skills for high } \\
\text { school / vocational school } \\
\text { teachers to strengthen brand } \\
\text { image. }\end{array}$ \\
\hline $\begin{array}{l}\text { Involvement of all sections in } \\
\text { the promotion strategy }\end{array}$ & $\begin{array}{l}\text {-Admin helps promote via } \\
\text { SMS reminder to prospective } \\
\text { students who have visited } \\
\text { campus. }\end{array}$ & $\begin{array}{l}\text { - Encourage the participation } \\
\text { of all employees actively in } \\
\text { making innovations to } \\
\text { increase the number of } \\
\text { prospective MARU (new } \\
\text { students). }\end{array}$ \\
\hline $\begin{array}{l}\text { Use of digital platform } \\
\text { promotion media }\end{array}$ & $\begin{array}{l}\text {-The campus website portal } \\
\text { is still centralized (main } \\
\text { branch). }\end{array}$ & $\begin{array}{l}\text {-Division designed an } \\
\text { attractive and connected } \\
\text { digital platform with all } \\
\text { campus branches. }\end{array}$ \\
\hline
\end{tabular}




\section{G. Change Planning}

a) "XY" Higher Education Institutions begin to empower students to become agents in the means of promotional strategies, for example providing monetary rewards by recommending prospective new students.

b) Collaborating with several high school / vocational schools in terms of holding exhibitions at educational events that will introduce the campus to prospective new students.

c) Inviting all stakeholders of the tertiary institution to be involved in supporting the promotion strategy.

d) Create a promotion strategy using an attractive and integrated digital platform.

\section{CONCLUSSION}

The use of the Soft System Methodology (SSM) approach in modeling knowledge capture $(\mathrm{KC})$ in the "XY" college promotion strategy which involves all stakeholders in the university and has been successful and prosperous through various stages by the case studies faced. The use of the Soft System Methodology (SSM) approaches in knowledge capture (KC) modeling in the "XY" college promotion strategy which involves all stakeholders in the university and has been successful and prosperous through various stages by the case studies faced.

\section{REFERENCE}

[1] Nalim, "Analisis Faktor yang Mempengaruhi Mahasiswa dalam Memilih Program Studi Pendidikan Bahasa Arab STAIN Pekalongan," Forum Tarb., vol. 10, no. 214-235, 2012.

[2] M. S. Rumetna, D. Manongga, and A. Iriani, "Penerapan Knowledge Capture Untuk Promosi Fakultas Menggunakan Soft System Methodology ( SSM ) ( Studi Kasus: Fakultas Teknik, Universitas Victory Sorong )," 2017, pp. 106-116.

[3] S. ur Rehman, A. S. Chaudhry, and S. A. Al-Alawi, "KM Coursework: Pooled Judgments of Experts," J. Inf. Knowl. Manag., vol. 12, no. 2, p. 1350017, 2013.

[4] M. Shujahat, M. J. Sousa, S. Hussain, F. Nawaz, M. Wang, and M. Umer, "Translating the impact of knowledge management processes into knowledge-based innovation: The neglected and mediating role of knowledge-worker productivity," J. Bus. Res., vol. 94, no. November 2017, pp. 442-450, 2019.

[5] P. Soto-Acosta, S. Popa, and I. Martinez-Conesa, "Information technology, knowledge management, and environmental dynamism as drivers of innovation ambidexterity: a study in SMEs," J. Knowl. Manag., vol. 22, no. 4, pp. 824-849, 2018.

[6] D. Sundiman, "THE EFFECT OF KNOWLEDGE MANAGEMENT ON THE STRATEGIC MANAGEMENT PROCESS MEDIATED BY COMPETITIVE INTELLIGENCE IN THE SMALL BUSINESS COMPANY,” J. Manaj. dan Kewirausahaan, vol. 20, no. 2, 2018.

[7] G. Santoro, D. Vrontis, A. Thrassou, and L. Dezi, "The Internet of Things: Building a knowledge management system for open innovation and knowledge management capacity," Technol. Forecast. Soc. Change, vol. 136, pp. 347-354, 2018.

[8] P. Checkland and J. Poulter, "Soft System Methodology," in Systems approaches to managing change: A practical guide, 2010, pp. 191-242. 
INTENSIF, Vol.4 No.1 February 2020

ISSN: 2580-409X (Print) / 2549-6824 (Online)

DOI: https://doi.org/10.29407/intensif.v4i1.13552

[9] A. Iriani and D. Manongga, "Using soft systems methodology as an approach to evaluate cheating in the national examination," J. Theor. Appl. Inf. Technol., vol. 96, no. 11, pp. 3344-3355, 2018.

[10] Munifah, A. Iriani, and S. Y. J. Prasetyo, "Penerapan Ekstraksi Pengetahuan Dalam Pembayaran Perkuliahan Menggunakan Soft System Methodology (Studi Kasus: Perguruan Tinggi X)," Transformatika, vol. 16, no. 2, pp. 144-152, 2019.

[11] E. M. Perdana, D. Manongga, and A. Iriani, "Model Konseptual bagi Pengembangan Knowledge Management di SMA Menggunakan Soft System Methodology," J. Teknol. Inf. dan Ilmu Komput., vol. 6, no. 2, p. 169, 2019.

[12] V. Peter Lodewyk Duan, D. Manongga, and A. Iriani, "Knowledge Capture Menggunakan Teknik Explore, Elaborate dan Execute Untuk Bagian Kesiswaan Sekolah," J. Inform. J. Pengemb. IT, vol. 3, no. 3, pp. 402-410, 2019.

[13] W. Boateng, "Evaluating the efficacy of focus group discussion (FGD) in qualitative social research," Int. J. Bus. Soc. Sci., vol. 3, no. 7, pp. 54-57, 2012.

[14] E. Sgourou, P. Katsakiori, I. Papaioannou, S. Goutsos, and E. Adamides, "Using soft systems methodology as a systemic approach to safety performance evaluation," in Procedia Engineering, 2012, vol. 45, pp. 185-193.

[15] L. Attefalk and G. Langervik, "SocioTechnical Soft Systems Methodology: A sociotechnical approach to Soft Systems Methodology Authors :," Building, 2001.

[16] R. R. Putri, L. Andrawina, and R. W. Witjaksono, "Perancangan Sistem Asset Management Berbasis Odoo Dengan Soft System Methodology Di Rumah Sakit Muhammadiyah Bandung," proceedings Eng., vol. 3, no. 2, 2016.

[17] C. L. hsing Chang and T. C. Lin, "The role of organizational culture in the knowledge management process," J. Knowl. Manag., vol. 19, no. 3, pp. 433-455, 2015. 